\title{
THE RIGHT TO FOOD BETWEEN THE JUSTICIABILITY AND THE PUBLIC SPHERE
}

\author{
HÉCTOR SILVEIRA ${ }^{1}$
}

\begin{abstract}
Basic food must be guaranteed by States as a fundamental right of all people. In this article we defend the hypothesis that the path of justiciability is insufficient to achieve full recognition of the right to food as a fundamental social right. A strong and active public sphere is needed to address the obstacles to this recognition today. Some of them are actually related to the inherited legal culture. And, on the other hand, that promotes the creation of new institutions to guarantee social rights. The constitutional State needs a "fourth estate" that guarantees fundamental rights and protects the common good from private powers.
\end{abstract}

Keywords: public sphere, fundamental good, right to food, fourth power, democracy, guarantees, fundamental rights.

Summary: 1. Food as a "Fundamental Good" 2. Guaranteeing the Right to Food 3. Obstacles to the ReCOGNITION OF THE Right TO FoOD a) The neoliberal thought b) The legacy legal culture d) Subjective rights of the individual and the affected e) Rights and justiciability: an inadequate defence strategy 3. A PuBLIC Sphere that Promotes and Protects the Right to Food a) A weak political community, which lacks public participation and does not safeguard the common good 4. A Public Sphere Wich Influences the Role of the Constitutional State: the Need for a "Fourth Power".

\section{Food as a "Fundamental Good"}

In the debate on the constitutional state, the Italian jurist Luigi Ferrajoli defends the introduction in the legal lexicon of a new category of goods: the "fundamentals" (Ferrajoli 2014,207 ; 2019). This new legal category would be composed of all those goods that are vital, indispensable, for life, such as water, air, lifesaving drugs, the oceans, the organs that make up the body human, and the basics foods. Ferrajoli proposes to divide them in three subgroups: a) common goods, the old res communes omnium, such as water, air and the environment, access to and the use of which is vital for all people and which therefore are the subject of fundamental law concerning freedom of use or enjoyment; $b$ ) non-transferable personal goods, such as the parts of the human body, that are the subject of fundamental rights of bodily integrity: freedom from lesions or violation; and c) social goods, such as life-saving or "essential" drugs or basic food and water, and as such the subject of fundamental social rights to health and subsistence (Ferrajoli 2011, 733-734; 2014, 213-214).

\footnotetext{
${ }^{1}$ Associate Professor SH, University of Barcelona, Spain (hsilveira@ub.edu).
} 
In the guaranteest constitutional state model that Ferrajoli proposes, these goods come under the protection of the so-called "sphere of the undecidable" 2 . As indispensable goods for human life, they must be placed outside the realm of action of the powers, publics and privates (Ferrajoli 2014, 213).

The right to food is recognised in international law as a human right, in the sense that everyone should be able to have "physical and economic access at all times to adequate food or means for its procurement" (CESCR GC12). In the words of Olivier de Schutter, the right to food is:

"the right to have regular, permanent and unrestricted access, either directly or by means of financial purchases, to quantitatively and qualitatively adequate and sufficient food corresponding to the cultural traditions of the people to which the consumer belongs, and which ensure a physical and mental, individual and collective, fulfilling and dignified life free of fear"'3

This requires ensuring that all people can feed themselves with food that is available - and therefore that there is sufficient produce for the whole of the population-accessible - so, every household must have sufficient means to obtain or produce the food they requireand in addition, adequate, in the sense that the food must be suitable to satisfy the needs of each person, taking into account their age, living conditions, health, occupation, sex, culture, etc.

The right to food is a transversal right without which it is impossible to understand the concepts of person and of citizen. The human condition depends on every person having available to them and being able to access basic sustenance. Only once this access to food is guaranteed can we talk of the possibility of exercising full citizenship (Rodotà 2012, 130). This right cannot be understood unless other principles and rights provided under a constitutional state are also respected such as, for example: respect for the dignity of the person and cultural diversity, the principle of not discriminating unfairly, the right to free personal development, autonomy, integrity and the inviolability of the person, and the principles of cooperation and decency.

\section{Guaranteeing the Right to Food}

The obligations of the states that are party to the International Covenant on Economic, Social and Cultural Rights (ICESCR) to guarantee the right to adequate food are clearly defined in international law. These obligations are both general and specific ${ }^{4}$. General obligations, such as guaranteeing the right to food and water, are exercised

\footnotetext{
${ }^{2}$ This sphere is in turn subdivided into two others: the "sphere of the undecidable that is", consisting of the rights to freedom and autonomy, which cannot be modified; and the "sphere of the undecidable that is not", formed by the set of social rights and which, in contrast to the former, must obligatorily be guaranteed and fulfilled by public authorities (Ferrajoli 2014, 54).

${ }^{3}$ De Schutter, Olivier (Un Special Rapporteur 2008-2014), (15-10-2020), http://www.srfood.org/es/derechoa-la-alimentacion

${ }^{4}$ On this issue, see Golay (2009).
} 
without discrimination, equally for all men and women, and require states to adopt measures by all means necessary to realise the right to food such as, for example, through legislation or acting in order to bring about the full effectiveness of the the right to food, making maximum use of the resources available (Arts. 2, 3 ICESCR). "Violations of the Covenant occur when a State fails to ensure the satisfaction of, at the very least, the minimum essential level required to be free from hunger." (CESCR, General Observation 12, paragraph 17).

Meanwhile, the specific obligations consist of respecting, protecting and ensuring observance of the right to food. Respecting, in the sense that public authorities must not arbitrarily deprive people of the the right to food, or hinder access to food ${ }^{5}$. Protecting requires states to regulate companies, social organisations or people who may threaten the right of others to adequate food and water ${ }^{6}$. Finally, ensuring observance of the the right to food, requires states to mobilise all their available resources to guarantee in a progressive fashion the full realisability of this right, particularly through drawing up new legislation. Specifically, the obligations that apply to states must initially be enacted through the adoption of measures that allow people to feed themselves via their own means. This requires providing the necessary facilities for people to enjoy the right to food. In second place, the states themselves must fulfil the right to food of all those who cannot feed themselves - children, the unemployed, the aged, etc. - whether through the distribution of food or implementation of social aid programmes ${ }^{7}$.

In international law the right to food has seen important advances in terms of specification, to the point where secondary instruments of guarantee have been created. For example, the Optional Protocol of the ICESCR, approved in 2008 and in force since 5th May 2013, opens the way for people to report infractions of their economic, social and cultural rights. States must therefore guarantee that all individuals can feed themselves. To this end, basic food must be available, accessible and adequate. Despite its recognition in international law, the main challenge for the right to food is to ensure that States also recognize it as a fundamental social right. But there are a number of obstacles against this.

\section{Obstacles to the Recognition of the Right to Food}

\section{a) The neoliberal thought}

The hegemony of neoliberalism in the governing institutions of Western countries in recent decades has become a checkpoint for the recognition of the right to food to be considered as a fundamental right. This is because for neoliberalism food must be treated as a commodity like any other. They should be part of the patrimonial goods, available, appropriable and tradeable, just like other goods, until now considered "common goods",

\footnotetext{
${ }^{5}$ Comisión, El derecho a la alimentación. Informe del Relator especial, Jean Ziegler, (16 de marzo 2006), Doc NUE/CN 4/2006/ 44, párrafo 22.

${ }^{6}$ Directrices de Maastricht relativas a las violaciones de los derechos económicos, sociales y culturales, párrafo 18 .

${ }^{7}$ Comité de Derechos Económicos, Sociales y Culturales, Observación general 12.
} 
such as water, air, oceans and forests. Likewise, the attempt to make basic foodstuffs the object of protection of a new social right clashes with the neoliberal tendency to privatize social rights and to reduce to a minimum everything that has to do with the public.

\section{b) The legacy legal culture}

Inherited legal culture is another important obstacle when theorizing as fundamental rights and freedoms acts and decisions which are the expression of private powers. One of the foundations of the legacy legal culture is the 1789 Declaration of the Rights of Man and of the Citizen, written by the French Constituent Assembly in order to tackle the extremely stratified society of the period, with its inequalities and feudal privileges. More to the point, in relation to the subject we are considering here, is the fact that the Declaration signified the triumph of the non-egalitarian liberal sector over the more democratic plebeianleaning Jacobin wing in the revolutionary process in France (Silveira 2017a). Through the call for "fraternity", the Jacobins intended to promote a programme of republican political economy with the objective of allowing citizens to be genuinely self-sufficient and economically independent so that they could, at the same time, be active, free and equal citizens. The Jacobins had no concept of a life of freedom without each individual necessarily being self-sufficient in terms of their own individual existence ${ }^{8}$. The Republic, as Antonio Domènech writes when he summarises the ideas of Robespierre, "must ensure the 'means of existence' for all; everyone must have sufficient property for them not to need to ask permission of anyone else in order to be able to subsist" $(2004,82){ }^{9}$

The Republican project of fraternity advocated a civil society in which everyone had their "right to existence" assured. Democracy was understood as "fraternity", in the sense that it was necessary to achieve a civil society, "that not only incorporated everybody, but in which everybody was also fully and reciprocally free, that is, equal in the old republican sense of the word" (Domènech 2004, 91-92) ${ }^{10}$. Therefore, we could say that the Jacobin political project already contemplated the right to food and water as a right that the community - the Republic - should guarantee, precisely so that the community itself could count on the political participation of all citizens ${ }^{11}$. After the Thermidorian Reaction, however, a philosophy which was entirely contrary to this project of fraternal democracy took root and a republic of mere owners was established, in which the (unlimited) right to property was recognised, together with economic freedom and non-universal censusbased democracy. From that moment, private property was consecrated as a "sacred and inviolable right", of which nobody "can be deprived" (art. XVII of the Declaration).

\footnotetext{
${ }^{8}$ Jefferson, for example, dreamt of a society based on small agricultural properties; Robespierre suggested a social right to existence guaranteed by the public authorities; and Paine wanted material income assigned unconditionally to all citizens, merely as a result of being such (Domènech 2013, 20).

9 "What is the first goal of society? To uphold the indefeasible rights of man. What is the first of those rights? The right to exist. So, the first social law is that which ensures the means to exist for all members of society; all the others are subordinate to this: property has only been instituted and guaranteed as the foundation of that law" (Translated from Domènech 2004, 82).

${ }^{10}$ The anti-Jacobin coup of 9th Thermidor 1794 put an end to this goal of "universal fraternal democracy" propounded by the Jacobin Republicans (Domènech 2004, 92).

${ }^{11}$ During the period of Jacobin democracy, from 10th August 1792 to 27th July 1794 (9th Termidor 1794), the universal right to existence was recognised and full male suffrage was achieved.
} 
In the bourgeois democracy of ownership another very clear dividing line is imposed, a real chasm, between the realm in which the private powers act, governed by the principle of free choice, and the sphere in which the public authorities act. In the following decades, throughout the 19th century, the liberal legal doctrine saw to it that this construct was consolidated, defining civil rights of freedom of choice as personal liberties, to be used in the private sphere, both by individual people and legal entities, to strike deals and do business (Ferrajoli 2014, 171-172). In this way, however, the doctrine hides or diminishes the importance of the "normative effects" that private powers produce in the legal sphere of other subjects, affecting the rights, liberties and interests of other people. Civil rights, which belong in the private sphere, are one thing and very different from the freedoms of people (Ferrajoli 2014, 52-53).

\section{c) Subjective rights of the individual and the affected}

In addition to this doctrinal doublespeak, we also have to consider two further elements that hinder recognition of fundamental goods within the category of fundamental rights. These are: a) the strictly individualist structure of right, they are constructed as subjective rights of the individual; $b$ ) and the fact that the legal procedures are predicated on the idea that it has to be the individual, the subject who is affected, who takes the initiative and sets in motion the principle of "cause of action" to defend their own interests and rights. But what happens if the goods in question belong to all or, to express it more clearly, they do not belong to anyone in particular? Who is going to take responsibility if there is no deprivation of a particular right or interest, but rather a deprivation of or non-compliance with a vital right or interest which belongs to everyone and on which, paradoxically, our other rights and interests depend? Is the legal architecture created under the modern rule of law sufficient to safeguard interests that correspond to us all? For Ferrajoli, the answer is that "the syntax of fundamental rights attributed to individual people as a guarantee of their personal needs and expectations, is not sufficient on its own". In order to achieve effective and complete guardianship of fundamental goods, it is necessary to move beyond the legal structure of individual subjective rights and broaden the principle of "cause of action" to other actors and institutions in the public sphere.

In recent years the right to food is gradually being recognised as a subjective right of the individual. In their constitutions, countries such as Bolivia, Ecuador, South Africa, Nicaragua and Colombia explicitly recognise the right to food and water as an individual human right of all people. Other countries explicitly include this right in the recognition of the human right to a decent standard of living or the right to personal development, which includes necessarily food, such as for example, in Belarus, Moldavia and Malawi. Still others recognise it as a governing principle of state policy, such as Nigeria and Sri Lanka; or they do so as a consequence of the ratification of international and regional treaties, as in the case of Uruguay; or as a consequence of the recognition of this right via by-laws, as in the case of the Dominican Republic. Furthermore, international organisations, such as the Committee for Economic, Social and Cultural Rights (CESCR), urge states to meet the principle of justiciability in relation to those rights enshrined in the International Covenant on Economic, Social and Cultural Rights (ICESCR). 
For its part, the CESCR encourages states to enact laws that allow the justiciability of the rights in the Covenant ${ }^{12}$. For example, it has requested that Colombia ratify the Optional Protocol of the ICESCR, meets fully its obligations under the Covenant and fosters full recognition and enjoyment of the rights contained therein, in its application of the 2030 Agenda for Sustainable Development in the national action plan. Similarly, it has reiterated to the Dominican Republic, in its fourth report, the need for the state to promote the applicability of all the rights enshrined in the Covenant at all levels of the legal system. The report says that the Committee has taken note of Article 74 of their Constitution but reminds them that the Covenant also ranks as constitutional and is directly applicable. It goes on to lament the fact that no information has been provided on cases of jurisprudence in which the rights in the Covenant have been invoked or directly applied by the national courts ${ }^{13}$. Likewise, in relation to Uruguay, the CESCR expresses concern about the justiciability of the Covenant, despite the fact that in this country the rights in the Covenant are directly applicable ${ }^{14}$.

Enacting and further developing the principle of justiciability is important in order to guarantee the right to food and, therefore, the CESCR must urge states to respect and abide by this principle. To this end, and also taking into account both the legal limits and the legal culture, an important step to guarantee compliance with the right to food on the part of both public and private authorities would be its constitutional recognition as an individual or fundamental right ${ }^{15}$. That said, however, the justiciability route to individual rights, despite their importance and the central role they play in the functioning of the rule of law, has the disadvantage of being a defence strategy and one perceived mainly as the recourse of individuals.

\section{d) Rights and justiciability: an inadequate defence strategy}

Generally in judicial procedures, the party who brings the legal action is the holder of a personal entitlement which has been interfered with. However, the holders of rights are not always in the best position to exercise their own fundamental rights; often due to not enjoying the economic conditions necessary to do so. Moreover, as a consequence, such individuals are in an even worse position when it comes to setting in motion actions to demand compliance with rights that protect goods that are not merely their own but

\footnotetext{
${ }^{12}$ On the relation between the CESCR and some of the signature states, see Silveira et al. (2018).

${ }^{13}$ In this way, it recommends that the state adopt the necessary measures to guarantee that all judicial decisions pay due respect to human rights, including economic, social and cultural rights, and to amend the effects of the sentences TC/0168/13 and TC/0256/14 of the Constitutional Court. The Committee indicates that the state should take note of its General Observation (1998) on the internal national application of the Covenant (6). Finally, it once again recommends, as in the previous report, that the state ratify the Optional Protocol of the Covenant (68).

${ }^{14}$ However, these rights are still scarcely visible and the Committee is concerned that certain ambiguities of the regulatory framework that affect processes of public interest make it difficult to demand these rights in the judicial setting. In this respect, the Committee recommends that the state take the necessary measures to guarantee the direct applicability of all the rights in the Covenant and it urges the state to pay attention to the Committee's General Observation no. 9 (1998) on the internal national application of the Covenant (8) (final observations, from the fifth report, of 20th July 2017 (E/C.12/URY/CO/5).

${ }^{15}$ In this regard, see Medina (2018) and Martín (2016).
} 
belong to everybody in general and to nobody in particular. This is where it becomes clear that, as Ferrajoli writes, the individualist model of rights as presented in the modern constitutional states is highly inadequate and insufficient to "ensure observance of the bonds imposed on the public sphere by social rights, fundamental goods and collective interests stipulated in the Constitution" $(2014,227)$.

It is true, as Rodotà says us, that rights model and configure democracy. It is also true, however, that without a truly democratic policy and without a solid and active public sphere, rights can easily fail to be worth the paper they are written on when left in the hands of those who have the power to take decisions over the lives of others; such as, for example, powers held by the private sphere. That is why, in addition to the call for new rights, we also need to demand that the political sphere really attends to the material needs of the people. To do so, it must genuinely face up to the private economic powers which, in addition to influencing and affecting people's lives in far-reaching ways, are not required to respect and safeguard fundamental rights or the common good, or at least not to the same extent as public authorities are obliged to. There should therefore emerge, as Rodotà calls for, a new politics that breaks through the armour-plating of the current political model and opens up a process of creation of new rights that grow from the grassroots of society upwards; and not from the top down, as happens at present (Rodotà 2012, 103104). Similarly, for Marramao, the hegemony of the neoliberal social and political project must be fought with a normative model of democracy that moves beyond the current liberal model, that is, through the construction of a public sphere that is not colonised by the institutions of representative democracy (Marramao 2011, 4).

All of this suggests that the defence of fundamental goods cannot be entrusted to the guarantee mechanisms constructed to date as part of the current constitutional states. Those mechanisms, as I have said, are generally only activated as a result of the actions of individuals who are directly affected by an interference with their personal rights. The route of justiciability of fundamental rights, and especially of economic, social and cultural rights, must necessarily be reinforced and complemented by new instruments of protection from within the public sphere ${ }^{16}$. Respecting and realising the right to food entails, as I have also said, guaranteeing access to food and ensuring a fair and just distribution of basic food to all the people who need it. But for that to happen, in addition to having available to them the legal instruments to claim their rights, the people affected must also have the support of a public sphere that takes responsibility for observance of this right. And that public sphere must have the powers and means necessary to demand fulfilment of the right

\footnotetext{
${ }^{16}$ By the public sphere we understand that space in social life where the rights and interests of all are at stake, and the consequent duties that we all have with respect to all others (absolute duties or erga omnes). This notion of the public sphere has little to do with that used by Habermas to refer to a space for public communication, debate and conflicts of opinion. Habermas conceives of the public political sphere as an "intermediary system of communication" between, on the one hand, public opinion formed from civil society and, on the other, the deliberations and negotiations of the political system (Habermas 2009, 159). The public sphere is where public opinion is formed which, at the same time, becomes political force (Fraser 2008, 146). In contrast, for Ferrajoli, the public sphere exists in opposition to the private sphere, where the principle of freedom of choice rules and legal entities make use of their civil rights while having their goods at their disposal (Ferrajoli 2011, 758 762).
} 
to food by both public and private entities. It is the public sphere which, under the rule of law, should also establish the limits and obligations to be borne by the private sphere, with the goal of protecting the general interest and fundamental rights and, in particular, in order to protect the weakest members of society ${ }^{17}$. In this public sphere a major role is played by the three branches of power: legislature, executive and judiciary. What is more, today the public sphere is greater than the state sphere and we constantly encounter more multi-state institutions and guidelines that intervene in the protection of the common good and human rights (the UN, the CESCR, the Human Rights Council, the FAO, the WHO, UNICEF, etc.).

\section{A Public Sphere that Promotes and Protects the Right to Food}

The formation of a solid public sphere empowered with the instruments necessary to protect fundamental goods and the general interest represents an important challenge for current constitutional states. And it is so because here we must also confront another of the strong postulates of liberal thought: a weak political community.

a) A weak political community, which lacks public participation and does not safeguard the common good

In liberal political ideology the representative democracy is not necessary to have a strong democratic political community and equipped with instruments with which to govern and power over the common good (Barcellona 1992, 107). The political institutions were designed within a liberal state where the rule of law ensured, in the first place, that public participation was not necessary for the functioning of the state and, in the second place, that public decisions did not have to impose on the life of the citizens Ovejero n.d. 3) ${ }^{18}$. The rule of law in European countries was built upon the preconceived idea that public institutions have to remain neutral when faced with progressive ideas emanating from civil society ${ }^{19}$.

\footnotetext{
${ }^{17}$ An example of a limit and obligation imposed from the public sphere is Section 51.1 of the Spanish Constitution which establishes that "The public authorities shall guarantee the protection of consumers and users and shall, by means of effective measures, safeguard their safety, health and legitimate economic interests". In this way: "Free enterprise is recognised within the framework of a market economy" (ibid. Section 38) and is limited by respect for the safety and health of consumers. Food safety is established together with a limit on the freedom of enterprise, in the sense that private economic initiatives cannot harm the dignity, safety, freedom or cultural diversity of the people (Rodotà 2012, 128).

18 The model of liberal democracy, Crouch writes, is characterised by: a) only being concerned with organising participative elections; b) giving considerable freedom to pressure groups so that they can go about their activities; and c) prohibiting the public sphere and the political system from interfering in the rationale behind the functioning of the economy (Crouch 2004, 35, 146).

${ }^{19}$ A current example of the limits of intervention by public authorities when facing the problems of society can be found in Art. 34.3 of the Charter of Fundamental Rights of the European Union where it is said that "In order to combat social exclusion and poverty, the Union recognises and respects the right to social and housing assistance so as to ensure a decent existence for all those who lack sufficient resources ...". When dealing with the issue of poverty and social exclusion, the EU has the audacity to say that it recognises the right to social and housing assistance: it only recognises a right to assistance! And that in an unequal society where groups of people do not have their basic needs guaranteed and live in poverty.
} 
This neutrality and lack of commitment on the part of public authorities, which are mainly responsible for safeguarding the common good, is reflected in citizens not feeling committed to -responsible for- each other and, in consecuense, remaining aloof from matters concerning the common good. The only obligations that are recognised are those derived from private agreements and pacts. In this way, the line that divides the public and the private has ended up also affecting the principle of civic responsibility, which is very weak or almost non-existent in the modern constitutional state. Under this type of state, citizens can exercise their right to vote but they have no means to supervise the actions of public authorities. Moreover, nothing guarantees that the public authorities will always act in defence of the common good and of fundamental rights.

Recent years have shown us that, under neoliberal policies, the defence of general interests cannot only be left in the hands of the institutions of the state ${ }^{20}$. Since the birth of the constitutional state, the powers of the political sphere have been subordinated to the powers of the private sphere, the economic powers, their success at reproducing themselves and, in consequence, managing to maintain alive the logic that ensures their survival: the logic of profit. The pre-constitutional elements -the right to property and the separation of the public sphere from the private- which the bourgeoisie managed to impose on the new political power of the constitutional state act, in this respect, as barriers to calls for democratisation and for the establishment of limits or meaningful bonds on the social powers (Barcellona 1992, 129).

New limits and obligations can be imposed on public authorities, as does indeed happen in the constitutional state, but not in relation to the private sphere. In this way, the economic powers see their rights and properties protected under the principle of freedom of choice and the treatment of civil rights as if they were rights to freedom (Ferrajoli 2014, 52). Meanwhile, it is one thing to say that the actions of public authorities accord with the rule of law and quite another to claim that their actions are always governed by the principle of the common good or the defence and prioritising of the general interest. As Hilary Wainwright points out, after analysing different experiences of public participation in European and Latin American cities, "the state institutions are not the same as the common or public good, and neither have they demonstrated that they are capable of looking after it" (Wainwright 2005, 195).

\footnotetext{
${ }^{20}$ The rights of different collectives - those with mortgages, the sick, dependents, schoolchildren, retired people, the unemployed, workers - are always pushed into the background in the face of the demands of an economic system that must maintain the logic that governs the exchange of goods: that of profit. It is enough to read through the principles and norms of the Treaty on the Functioning of the European Union (Arts. 26.2, 63, 107 and 106.2) or the Fiscal Compact (Title III of the Fiscal Stability Treaty), approved on 2nd March 2012, which contains the principles of stability or budgetary excess, or the latest reform of the European constitutions, such as Section 135 of the Spanish Constitution, to see the extent to which economic logic rules or is imposed on any other, such as political logic or the logic of rights. Or see the Spanish Royal Decree, Law 20/2012, of 13th July, concerning measures to guarantee budgetary stability and to foster competitiveness, which establishes cuts in Social Security benefits and in the application of Law 39/2006 concerning dependency, reducing the maximum amounts of economic benefits for home care; and Executive Order ASC/471/2010, of 28th September, which limits the right to home help for certain people who lack decision-making capacities, replacing it by care in nursing homes.
} 
It is true, however, that the constitutions of the post-war era have placed new obligations on the state: social rights, some of which appear as fundamental rights, as is the case with the right to education in the Spanish legal system. These legal instruments are still, however, insufficient to guarantee full compliance with the obligations. Few of the social rights have become recognised as individual rights or as fundamental rights. New institutions are needed which genuinely guarantee fundamental goods and in addition defend what is common to all people who live together in a community.

Thus, in order to achieve effective protection of fundamental rights, the public sphere must have at its disposal new instruments that strengthen the principle of "cause of action" when such rights are violated. Under the current constitutional state and within the framework of the reorganisation of political and legal powers resulting from globalisation, it is essential, for example, to guarantee access to justice as a universal right. Indeed, in Latin America we can find two constitutional watchdog institutions that exemplify construction of the necessary mechanisms, within the public sphere, to defend and guarantee fundamental goods such as the right to food. These two institutions are, the Public Defender's Office which forms part of a public ministry of justice; and a separate public body with the power to call on the judiciary to intervene (the public ombudsman or defensorías públicas) (2014, 227-229). Something similar to these ombudsmen could be created in other states to oversee the way in which public authorities fulfil their obligations; but also how private bodies act to safeguard the basic rights that guarantee fundamental goods as a whole - common goods, non-transferable personal goods and social goodsand particularly the RAF.

Be that as it may, the protection of fundamental goods in the current constitutional state demands somewhat more than a reform of the existing institutions. It requires new social and political praxis that brings with it new relations between the individual and the political institutions in the community. To counter the current neoliberal hegemony and the limits and shortcomings that the current predominant legal culture presents, imbued as it is with the dogma of individualism and the strict separation of the political and economic spheres, we need to promote, as Barcellona expresses it, "instituent praxis" that transforms meanings and the institutions thus established (Barcellona 1996, 78-79). This praxis should lead to the formation of what I refer to elsewhere as a "fourth power" within the constitutional state.

This fourth branch of power would entail the creation of new public institutions whose realm of influence - through enacting checks and balances - is the powers of the state. The institutions would act with the aim of guaranteeing and protecting vital goods, allowing this project to advance while at the same time helping to consolidate the culture and practices that promote the democratic principle and the protection of fundamental goods. The fourth branch of power would be comprised of three types of institution: monitoring, judicial and deliberative. The institutions responsible for monitoring would oversee the use of public resources by public and private powers. Meanwhile, the judicial institutions would analyse and evaluate the degree of compliance with rights and fundamental goods on the part of those same powers. Finally, the deliberative institutions are those which give voice to civil society, enabling citizens 
and associations to debate and put forward proposals concerning general interests or shared goods (Silveira 2017a; 2017b).

\section{The Public Sphere Articulation with the Powers of the Role of the Constitutional State: the Need for a "Fourth Power"}

The limits of the current political sphere of liberal democracy could be transformed by constructing a new sphere of influence that operates between individuals, the organisations of civil society and the political institutions of representative democracy. The sphere of influence of the so-called participative democracy within the current model could become the instrument that allows us to move towards a more fully democratic society, with more citizen control and more political equality. Furthermore, public institutions that come under greater control from citizens and that count on the participation of independent social actors can also come to have a strong influence on private powers and interests, as can be seen through the experiences of public participation in Luton, Porto Alegre and Newcastle (Wainwright 2005, 195, 209). As opposed to the culture of the new neoliberal subject, we must offer a different culture that reinforces the idea of the democratic citizen who is committed to interests that are shared by all and, more specifically, to everything that is related to fundamental rights and goods, many of them already recognised in the corresponding legal systems.

This culture requires major efforts in education, training and empowerment of the members of the community. Today, the practice of the democratic principle and the maintenance of the principle of the rule of law demand that we achieve a cultural hegemony that inverts the current process of individualisation and the loss of ties between different members of the community. This issue of the "social ties and, therefore, of the determination of our shared goals," Barcellona writes, "is not in the slightest something nostalgic, but rather a novel urgency" $(1992,125)$. Moreover, in order to achieve this new culture that promotes new social bonds, we require social and institutional spaces that allow us to implement and spread it. These new spaces and institutions will form the backbone of what I have here been referring to as the fourth power ${ }^{21}$.

Public opinion must find the means by which to reach the institutions that will allow it to intervene with efficacy and full legitimacy in the political system. The fourth branch of power is in no way intended to replace or leave to one side the existing mechanisms of representation and institutional participation; rather it is an attempt to construct a new institutional space governed by the law and which acts as a mediator between civil society and the institutions of the political system. It would act as the driving force for transformation of the public authorities already instituted, performing

\footnotetext{
${ }^{21}$ This proposal for the institutionalisation of a fourth branch of power at the heart of state governance in order to improve the relations between civil society and the political system shares many of the ideas and considerations of Habermas and Fraser on the role of the public sphere in deliberative democracy; of the "associative democracy" proposal of Cohen and Rogers $(1998,9)$; of the "state as the newest social movement" of Sousa Santos (1999); and of Mouffe with her idea to "radicalise the modern democratic tradition" (Mouffe 1999).
} 
functions of monitoring and follow-up of the organs of government and also drawing up new political proposals, in the search for better government and more democracy. It would thus accord with the philosophy that it is possible to "change the world without taking power," as Wainwright proposes, following the path that Holloway previously opened up. The possibility of achieving social change and transformation depends on the correlation of the forces that at each given moment exist between the political powers and social power, within both political institutions and social organisations (Wainwright 2005, 197).

The objective of the institutions of the fourth power is to put into practice the two strands of the principle of participation in deliberative democracy: as the means through which to increase the capacity for self-decision and self-organisation of communities; and as a means to improve citizen control of the resources and institutions of the state (Wainwright 2005, 84). The institutions of the fourth power, therefore, form spaces of participation and communication channels through which the members of the community can participate in and influence both the public agenda and the institutions of government of the community (Politikon 2014, 263). They open the way for citizens to be able to participate in the general affairs of the community and to transmit their voice to the institutions of government, in addition to supervising the functioning of these latter bodies and safeguarding respect for and compliance with the rights, obligations and goods defined as basic and fundamental for the community. In this way, the fourth branch of power, representing the goals, aims and desires of the public sphere and civil society before the political system, and institutionalising checks and balances as well as communication channels with the public authorities, can become an instrument and driving force of the democratic principle in the community, and of the defence of fundamental rights and the common good.

\section{Biblography}

BARCELlONA, P. (1992) Postmodernidad y Comunidad. El regreso de la vinculación social, Trotta, Madrid, [ed. original de 1990, Il ritorno del legame sociale, BollatiBoringhieri, Torino].

BARCELLONA, P. (1996), L’individuo sociale, Genova, Costa \& Nolan.

COHEN, J. y ROGERS, J. (1998) “Asociaciones secundarias y gobierno democrático”, en Zona Abierta, n. 84-85

CROUCH, C. (2004) Postdemocracia, Taurus, Madrid.

DOMÈNECH, A. (2004) El eclipse de la fraternidad. Una visión republicana de la tradición socialista, Crítica, Barcelona.

DOMÈNECH, A. (2013) "La humanidad es una sola, no un cúmulo de culturas cerradas", entrevista en La Habana, en www.sinpermiso.info, (7 de enero 2013.

FERRAJOLI, L. (2011) Principia iuris. Teoría del derecho y de la democracia, (vol. I-Teoría del derecho), (vol. II-Teoría de la democracia), Trotta, Madrid.

FERRAJOLI, L. (2014) La democracia a través de los derechos, Trotta, Madrid, 
FERRAJOLI, L. (2019), Manifiesto por la igualdad, Trotta, Madrid.

FRASER, N. (2008), Escalas de justicia, Herder, Barcelona.

GOLAY, Ch. (2009) Derecho a la Alimentación y Acceso a la Justicia: Ejemplos a nivel nacional, regional e internacional, FAO, Roma.

HABERMAS, J. (2009), “¿Tiene aún la democracia una dimensión epistémica? Investigación empírica y teoría normativa”, en Id., ¡Ay, Europa!, Trotta, Madrid.

MARRAMAO, G. (2011) "La lógica del capital está en una fase terminal, al igual que la lógica de la democracia”, en El jinete insomne (blog), 30 de octubre.

MARTÍN LÓPEZ, M.A. (2016) El derecho a la alimentación ante los riesgos del futuro, en Araucaria. Revista Iberoamericana de Filosofía Política y Humanidades, n. 18.

MEDINA, J.M. (2018) El derecho humano a la alimentación en España (mecanoscrito)

MOUFFE, Ch. (1999) El retorno de lo político, Paidós, Barcelona.

OVEJERO, F. “Culturas democráticas y participación (Para una crítica del elitismo democrático)", en http://www.oei.es/cultura2/ovejero.htm.

POLITIKON (2014) LA URNA ROTA, Debate, Madrid.

RODOTÀ, S. (2012) Il diritto di avere diritti, Laterza, Roma, [trad. en español: El derecho a tener derechos, Trotta, Madrid, 2014].

SILVEIRA, H. (2017a), El cuarto poder y la protección del bien común, en Crítica penal y poder, n. 12.

SILVEIRA, H. (2017b), "Más allá de la gobernanza democrática. El cuarto poder y la protección de lo común, en Crítica penal y poder, n. 13.

SILVEIRA, H. et alt. (2018) Hasta qué punto los estados de Colombia, Costa Rica, Chile, El Salvador, República Dominicana y Uruguay cumplen con las observaciones del Comité DESC en relación con el derecho a la alimentación, (en prensa).

SOUSA SANTOS, B. de (1999) Reiventar la democracia, reiventar el estado, Sequitur, Madrid.

WAINWRIGHT, H. (2005) Cómo ocupar el Estado. Experiencias de democracia participativa, Icaria, Barcelona.

Received: January $7^{\text {th }} 2020$

Accepted: June $12^{\text {th }} 2020$ 